\title{
Nutritional and Sensory Evaluation of Mango Pulp and Milk Powder Incorporated Sponge Cake
}

\author{
H.N. Ramya* and S. Anitha \\ Department of Food Science \& Technology College of Agriculture, \\ Hassan - 573225, Karnataka, India \\ *Corresponding author
}

\section{A B S T R A C T}

\begin{tabular}{|l|}
\hline Key w o r d s \\
Mango pulp, Milk \\
powder, Sponge \\
cake, Nutritional \\
quality, Sensory \\
quality \\
\hline Article Info \\
\hline $\begin{array}{l}\text { Accepted: } \\
\text { 05 June 2020 } \\
\text { Available Online: } \\
\text { 10 July 2020 }\end{array}$ \\
\hline
\end{tabular}

Sponge cake prepared by partial substitution of wheat flour with mango pulp and milk powder at different concentrations (control, 35\%, 35\%, 50\% and $50 \%)$ and $(5 \%, 10 \%, 5 \%$ and $10 \%)$ were investigated for the physicochemical, nutritional and organoleptic characteristics. Results showed sponge cake incorporated with mango pulp (50\%) and milk powder (10\%) to have high dietary fiber, fat, moisture, ash, protein vit-A, fiber and calorie, hydrolysis and predicted glycemic index compared with the control. Increasing the levels of mango pulp and milk powder in sponge cake had significant impact on the volume, firmness and color. Sensory evaluation showed sponge cake formulated with 50\% mango pulp and $10 \%$ milk powder to be the most acceptable. Mango pulp and milk powder have high potential as Protein -rich ingredients and can be utilized in the preparation of cake and other bakery products to improve the nutritional qualities.

\section{Introduction}

Cake is baked batter made from flour, sugar, salt, baking ingredients, shortening, milk, eggs, and certain additives aroma. Cake is food that rich of protein, carbohydrate, fat, calcium and phosphorus. Cakes are also contained vitamin A, vitamin B1 and vitamin C (Kamaljit.et.al 2010).

Mango (Mangifera indica L.) is one of the most important tropical fruits in the world with regard to production and consumers acceptance. Mango is one of the leading fruit crops of our country and considered to be the 'King of Fruits.' Mangoes are juicy stone fruit (drupe) from numerous species of tropical trees belonging to the flowering plant genus Mangifera, cultivated mostly for their edible fruit. The majority of these species are found in nature as wild mangoes. Mangoes are native to south Asia, from where "common mango" or "Indian mango" has been distributed worldwide to become one of the 
most widely cultivated fruits in tropics. The mango fruit is a laterally compressed, fleshy drupe, containing mesocarp (mango pulp). Its edible part is pulpy, firm to tender, and has its own characteristic flavour. Therapeutic properties are: prevents cancer since they are rich in antioxidants; lowers cholesterol due to high level of fibre; improves eye health as it contains vitamin-A. Mangoes are generally sweet and can be used in Bakery products.

Milk powders contain all twenty-one standard amino acids, the building blocks of proteins, and are high in soluble vitamins and minerals. Powdered milk or dried milk is a manufactured dairy product made by evaporating milk to dryness. One purpose of drying milk is to preserve it; milk powder has a far longer shelf life than liquid milk and does not need to be refrigerated, due to its low moisture content. Another purpose is to reduce its bulk for economy of transportation. Powdered milk and dairy products include such items as dry whole milk, nonfat (skimmed) dry milk, dry buttermilk, dry whey products and dry dairy blends.

Milk contains dozens of other types of proteins beside the caseins. They are more water soluble than the caseins and do not form large structures. Because these proteins remain suspended in the whey, left behind when the caseins coagulate into curds, they are collectively known as whey proteins. Whey proteins make up approximately twenty percent of the protein in milk, by weight. $\beta$ lactoglobulin, $\alpha$-lactalbumin and proteosepeptone are the most common whey protein by a a large margin.

Wheat Flour provides the structure in baked goods. Wheat flour contains proteins that interact with each other when mixed with water, forming gluten. It is this elastic gluten framework which stretches to contain the expanding leavening gases during rising. The protein content of a flour affects the strength of a dough. The different wheat flour types contain varying amounts of the gluten forming proteins.

Eggs serve many functions in baked goods. They add flavor and color, contribute to structure, incorporate air when beaten, provide liquid, fat, and protein, and emulsify fat with liquid ingredients. Reducing or omitting egg yolks can result in less tenderness. Reducing or omitting egg whites can result in less volume. Cakes made without the emulsifying action from the egg yolk may not have a uniform flavor and texture.

Generally, the Sponge Cake is kind of cake which has light batter and foam as the characteristic. Sponge cake is made from three main ingredients such as eggs, flour, sugar and the addition of liquid. Rajeev Bhat (2011) evaluated processed green and ripe mango peel and pulp flour in terms of chemical composition, antioxidant components and functional properties. Results of the study showed that compared to commercial wheat flour, mango flour was significantly low in moisture and protein but were high in crude fibre, fat and ash content. Mango flour exhibited high values for bioactive or antioxidant compounds compared to wheat flour. Ajayi et al., (2005) studied the influence of mango mesocarp flour supplement to micronutrient, physical and organoleptic qualities of wheat-based bread. Water absorption capacity of the composite flour samples slightly decreased, with increased level of mango flour substitution. Mango mesocarp flour enriched the micronutrient contents of the bread and imparted acceptable colour appeal to it. Pandya (2009) reported that as compared to cow milk, buffalo milk is richer in total proteins, particularly caseins and whey proteins. However, the proportion of various protein fractions is similar in milk of both 
species. Distinct differences exist in the physico-chemical makeup of casein in buffalo and cow milk. Buffalo casein has superior whitening as compared to cow casein due to a higher proportion of calcium present in it. Enrichment of foods with supplements like protein, fiber, minerals and vitamins are of current interest because of nutritional awareness of consumers. The present study was under taken to achieve the following objectives that include to analysis the proximate composition of mango pulp and milk powder. And to standardise the production of cake made from wheat flour blended with mango pulp and milk powder. Also to study the Nutritional and sensory quality of enriched sponge cake.

\section{Materials and Methods}

The experiment was plan to study the effect of incorporation of different levels of mango pulp and milk powder in order to produce good quality sponge cake. Mango fresh fruit was collected from local market of Hassan city, Karnataka, India. The fruit weighing 1000 grams Which were sorted, washed, peeled, sliced and pulped using fruit pulper. Remaining Raw materials such as Wheat flour (Maida), Sugar powder, Fat (oil), Baking powder and Milk Powder purchased from local market.

\section{Composition analysis}

The proximate composition of moisture, protein, ash, Acid insoluble ash, fat, crude fiber, Carbohydrates, iron and Vit-A ( $\beta$ carotene) and Energy for all the Ingredients were analysed by methods described by AOAC (2010).

\section{Recipe formulation}

The initial stage of recipe formulation was selection and standardization of bakery products (sponge cakes). Various ratios of wheat flour, mango pulp and milk powder were used to standardize the sponge cakes. Four variations were prepared $-\mathrm{S}$ (Standard $100 \%$ flour), TS 1 (wheat flour $60 \%$, mango pulp $35 \%$ and milk powder $5 \%$ ), $\mathrm{TS}_{2}$ (wheat flour $55 \%$, mango pulp $35 \%$ and milk powder $10 \%) \%$ ), $\mathrm{TS}_{2}$ (wheat flour $55 \%$, mango pulp $35 \%$ and milk powder $10 \%$ ) $\mathrm{TS}_{3}$ (wheat flour $45 \%$, mango pulp $50 \%$ and milk powder $5 \%$ ) and $\mathrm{TS}_{4}$ (wheat flour $40 \%$, mango pulp $50 \%$ and milk powder $10 \%$ ).

\section{Product development}

The cakes were prepared after the flour preparation, following a standard formulation, with the addition of four different levels of mango pulp and milk powder. Table shows the ingredients utilized in the cake preparation. The ingredients sugar and vegetable oil were homogenized with an electric mixer at medium speed for 5 minutes; next wheat flour, milk powder, mango pulp and water were added to the mixture. The mixture was homogenized until it was uniform in consistency and the baking powder was added and homogenized for $3 \mathrm{~min}$.

The batter was placed into aluminium pans, previously oiled and covered with a butter paper and baked in a Hot-air oven pre-heated to $180{ }^{\circ} \mathrm{C}$ for $25-30$ minutes. After cooling, the cakes were weighed and sliced in order to calculate the total cake yield and samples were taken the baked cakes were cooled and packed into LDPE bags and kept in a refrigerator at $5^{\circ} \mathrm{C}$ for further Sensory Evaluation and chemical analysis.

\section{Sensory evaluation of standardized cakes}

Evaluation of texture involves measuring the response of a food when it is subjected to forces such as cutting, shearing, chewing, compressing, or stretching. Food texture depends on the rheological properties of the food. Subjective measurement of texture gives an indirect evaluation of the rheological 
properties of a food (Ugwuona et al., 2012).

The control sample and samples of cakes prepared with addition of different levels of mango pulp and milk powder were evaluated by fifteen panellists for the sensory qualities of colour, aroma, taste, texture and overall acceptability using a 5-Point Hedonic Scale. Sample with highest acceptability was awarded a score of 5 and 1for the least acceptable. The mean value of the scores from fifteen panellists was then calculated. The most acceptable cake will be analysed for nutrients content of the cakes.

\section{Proximate analysis}

The control and sample prepared with added Mango pulp and milk powder incorporation having the highest sensory acceptance (sample $\mathrm{TS}_{4}$ ) were analysed for the moisture, fat, protein, ash, crude fibre and vitamin A contents as per the methods of AOAC (2010).

\section{Evaluation of physical properties}

Measurement of Weight, Height, Volume and Density: The sponge cake was weighed after cooling at room temperature for an hr. using weighing balance and the reading ( $\mathrm{g}$ ) was recorded. The height $(\mathrm{cm})$ of sponge cake was measured using ruler. Three measurements were taken from different sides of sponge cakes. The average of the three points was recorded. The volume $\left(\mathrm{cm}^{3}\right)$ of sponge cake was determined 3 using rapeseed displacement method as described in the AACC method. The seeds were poured into an empty container to measure its volume. The rapeseeds in the container then measured in a measuring cylinder and marked as A. Subsequently, the sponge cake was placed into a same container and rapeseeds were poured in until the cake was covered. The rapeseeds were again measured in a measuring cylinder and marked as B. The volume of the sponge cake was calculated by subtracting the value of A to B. The density $\left(\mathrm{g} / \mathrm{cm}^{3}\right)$ of the sample was calculated by 3 dividing weight $(\mathrm{g})$ of sample with volume $\left(\mathrm{cm}^{3}\right)$.

\section{Statistical analysis}

Statistical Analysis was done using computer software. The analysis was done by application of ANOVA at 5\% significance level.

\section{Results and Discussion}

\section{Sensory analysis}

The mean scores for sensory evaluation of control, $\mathrm{TS}_{1}, \mathrm{TS}_{2}, \mathrm{TS}_{3}$ and $\mathrm{TS}_{4}$, samples are shown in Table II. Sample $\mathrm{TS}_{4}$, containing $50 \%$ mango pulp and $10 \%$ milk powder had the highest scores for colour, aroma, taste and the overall acceptability. While the increased protein content through the addition of milk powder seems to have contributed to improvements in colour, aroma and taste, increased Vitamin A ( $\beta$-carotene) content in mango pulp added sponge cakes resulted in a product with a spongy more acceptable texture.

Kawai et al., (2016), each type of cake has a different texture, aroma, and flavor. It depends on the ingredients, the processing, and the level of maturity. Texture, aroma, and flavor of cake give an effect to the quality of the cake which ultimately and it cause the effects of consumer acceptance of the cake. Some kind of cake texture are: soft, chewy, wet, and watery. While some kind of aroma is: weak, average, and strong. Then some kind of flavor are: salty, sweet, and spicy.

A slight low acceptable taste was observed in samples $\mathrm{TS}_{1}, \mathrm{TS}_{2}$ and TS ${ }_{3}$ containing $35 \%$, $35 \%$ and $50 \%$ mango pulp and 5\%,10\% and $5 \%$ milk powder respectively. The scores for these samples for colour and aroma were also 
lower than the sample $\mathrm{TS}_{4}$ containing $50 \%$ mango pulp and $10 \%$ milk powder. Sample TS 4, which was more acceptable than the other three samples containing mango pulp and milk powder was then compared with the control sample for its physical properties and chemical composition.

\section{Proximate analysis}

The control sample and sample containing 50 $\%$ mango pulp and $10 \%$ milk powder $\left(\mathrm{TS}_{4}\right)$ were analysed for the contents of moisture, protein, fat, ash, crude fibre and Vit-A ( $\beta$ carotene)iron contents by the methods of AOAC. The results of analysis are shown in Table IV. The sample $\mathrm{TS}_{4}$ was found to contain highermoisture content possibly due to the highercrude fibre content binding more amount of water in the sponge cakes. The protein content was significantly higher because of the added milk powder in sample $\mathrm{TS}_{4}$.

\section{Physical properties and texture profile of sponge cakes}

Table IV presented the results for physical properties (weight, height, volume and density) of sponge cake. There was a significant increase in the weight of sponge cakes in the sample $\mathrm{TS}_{1}(272.24 \mathrm{~g})$ and control (260.40g) compared with $\mathrm{TS}_{4}$ (258.71g). However, it did not affect the height of the composite cake $(4.40,4.16$ and $4.5 \mathrm{~cm}$ respectively). The incorporation of mango pulp and milk powder into sponge cake preparation significantly $(\mathrm{p}<0.05)$ decreased the volume of the composite sponge cakes (1051.66, 1073 and $1195 \mathrm{~cm}$ respectively).

This three could be counteracted by the dilution of gluten of wheat flour was replaced with mango pulp. Gluten is vital to enhance the structural framework; rising in volume of the baked products.
Lee-Hoon Ho et al., (2017) low amount of gluten can cause reduction in gas retention capacity during baking, thereby reducing the volume of the baked product. The cake incorporated with sweet potato had decreased the volume of cake. There is increase in volume of cake $\left(\mathrm{TS}_{4}\right)$ prepared by incorporation of milk powder along with mango pulp compared to control and $\mathrm{TS}_{1}$.

\section{Moisture content}

The moisture content of 3 different samples of control, $\mathrm{TS}_{1} \mathrm{TS}_{4}$ cakes prepared with different levels of mango pulp milk powder were in the range of $10-14 \%$ (Table V). The levels of mango pulp increase in cake, the moisture content also increases because, the moisture content in the mango pulp is more compare to wheat flour. The moisture content of the FPW (Fruit Pulp Waste) powder was 5.96\%. (Richa Singh 2016)

\section{Protein content}

Different samples control, $\mathrm{TS}_{1}$ and $\mathrm{TS}_{4}$ contained protein content of 14, 15 and 17 respectively. In present study it was observed that protein content of mango sponge cake (Table 4) was much higher than that of control cake. The total protein content for FPW powder was calculated to be $2.6 \mathrm{~g} / 100 \mathrm{~g}$ (Richa Singh, 2016)

\section{Crude fibre content}

The fibre content in the $\mathrm{TS}_{1}$ and $\mathrm{TS}_{4}$ were higher than the control. Addition of mango pulp to cake increases the fibre content compared to control. It is the residue that remains after a food sample has been subjected to treatment by acid or alkali under standard conditions. As per analysis, the crude fiber content of the fruit pulp waste was $8.5 \%$. 


\section{Fat content}

Fat content of mango pulp do not contain much fat and hence the content of fat was very less. Fat content of sample $\mathrm{TS}_{4}$ was higher $(6.5 \%)$ due to addition of $10 \%$ milk powder. As per the nutritive analysis the fat content of milk powder was $26.7 \%$.similar content was reported by other studies.

\section{Ash content}

Different samples control, contained $1 \%$, $1.7 \%$ and $2.6 \%$ respectively. In present study it was observed that ash content of mango pulp and milk powder incorporated cake was much higher than that of control cake. The mineral ash content of FPW powder as analyzed was $1.4 \mathrm{~g} / 100 \mathrm{~g}$ (Richa Singh, 2016).

Table.1 Formulations used for the preparation of sponge cake incorporated with mango pulp and milk powder (percentage)

\begin{tabular}{|l|c|c|c|c|c|}
\hline \multicolumn{1}{|c|}{ Ingredients (g) } & Control & TS $_{\mathbf{1}}$ & TS $_{\mathbf{2}}$ & TS $_{\mathbf{3}}$ & TS $_{4}$ \\
\hline Wheat flour & 100 & 60 & 55 & 45 & 40 \\
\hline Mango pulp & - & 35 & 35 & 50 & 50 \\
\hline Milk powder & - & 5 & 10 & 5 & 10 \\
\hline Butter/oil & 10 & 10 & 10 & 10 & 10 \\
\hline Sugar & 20 & 20 & 20 & 20 & 20 \\
\hline Baking powder & 4.0 & 4.0 & 4.0 & 4.0 & 4.0 \\
\hline Salt & 2.0 & 2.0 & 2.0 & 2.0 & 2.0 \\
\hline Egg (Nos) & 2 & 2 & 2 & 2 & 2 \\
\hline
\end{tabular}

Note: - All ingredients are expressed; TS: - Test sample

Table.2 Mean scores for the sensory evaluation of sponge cakes samples

\begin{tabular}{|l|c|c|c|c|c|}
\hline Sensory qualities & Control & TS $_{\mathbf{1}}$ & TS $_{\mathbf{2}}$ & $\mathbf{T S}_{\mathbf{3}}$ & $\mathbf{T S}_{\mathbf{4}}$ \\
\hline Colour & 4 & 2 & 3 & $\mathbf{3}$ & $\mathbf{4}$ \\
\hline Aroma & 3 & 4 & 4 & $\mathbf{4}$ & $\mathbf{5}$ \\
\hline Taste & 4 & 3 & 5 & $\mathbf{5}$ & $\mathbf{5}$ \\
\hline Consistency & 4 & 3 & 4 & $\mathbf{4}$ & $\mathbf{4}$ \\
\hline Overall acceptance & 3 & 3 & 4 & $\mathbf{3}$ & $\mathbf{5}$ \\
\hline
\end{tabular}

Note; - Score $-5=$ highly acceptable, $4=$ moderately acceptable, $3=$ neither acceptable nor not acceptable, $2=$ poorly acceptable, $1=$ Very poorly acceptable

Table.3 Nutritional composition of mango pulp and milk powder were analysed using AOAC methods

\begin{tabular}{|c|c|c|c|c|c|c|c|c|c|}
\hline Ingredients & Moisture \% & $\begin{array}{l}\text { Protein } \\
\%\end{array}$ & $\begin{array}{l}\text { Fat } \\
\%\end{array}$ & $\begin{array}{l}\text { Ash } \\
\%\end{array}$ & $\begin{array}{l}\text { Fiber } \\
\%\end{array}$ & $\begin{array}{l}\text { Iron } \\
\text { mg }\end{array}$ & $\begin{array}{l}\text { Carbohydrates } \\
\text { g }\end{array}$ & $\begin{array}{l}\text { Vit-A }(\beta- \\
\text { carotene) mg }\end{array}$ & $\begin{array}{l}\text { Energy } \\
\text { kcal }\end{array}$ \\
\hline Mango pulp & 74.6 & 0.49 & 0.56 & 0.29 & 0.33 & 0.7 & 19 & 50 & 85 \\
\hline Milk powder & 3.5 & 25.8 & 26.7 & 6.0 & - & 0.6 & 38 & 380 & 496 \\
\hline Wheat flour & 13.3 & 11.0 & 0.9 & 0.6 & 0.3 & 2.7 & 73.9 & 25 & 348 \\
\hline
\end{tabular}


Table.4 Physical properties of sponge cakes

\begin{tabular}{|l|c|c|c|}
\hline Parameter & Control & TS $_{1}$ & TS $_{\mathbf{4}}$ \\
\hline Physical properties & & & $\mathbf{2 5 8 . 7 1} \pm \mathbf{8 . 1 9}$ \\
\hline Weight $(\mathrm{g})$ & $\mathbf{2 6 0 . 4 0} \pm \mathbf{6 . 3 4}$ & $\mathbf{2 7 2 . 2 4} \pm \mathbf{0 . 4 3}$ & $\mathbf{4 . 5} \pm \mathbf{0 . 4 8}$ \\
\hline Height $(\mathrm{cm})$ & $\mathbf{4 . 1 6} \pm \mathbf{0 . 2 2}$ & $\mathbf{4 . 4 0} \pm \mathbf{0 . 1 2}$ & $\mathbf{1 1 9 5} \pm \mathbf{5 . 0 1}$ \\
\hline Volume $\left(\mathrm{cm}^{\mathbf{3}}\right)$ & $\mathbf{1 0 7 3} \pm \mathbf{5 . 2 0}$ & $\mathbf{1 0 5 1 . 6 6} \pm \mathbf{2 . 7 9}$ & $\mathbf{0 . 2 2} \pm \mathbf{0 . 0 1}$ \\
\hline Density $\left(\mathrm{g} / \mathrm{cm}^{\mathbf{3}}\right)$ & $\mathbf{0 . 2 4} \pm \mathbf{0 . 0 1}$ & $\mathbf{0 . 2 5} \pm \mathbf{0 . 0 1}$ & \\
\hline
\end{tabular}

Note: $\mathrm{TS}_{1}-35 \%$ Mango pulp and 5\% Milk powder; $\mathrm{TS}_{4}-50 \%$ Mango pulp and 10\% Milk powder

Table.5 Chemical composition of mango pulp and milk powder incorporated cake

\begin{tabular}{|l|c|c|c|}
\hline \multicolumn{1}{|c|}{ Sample/Nutrients (\%) } & Control & $\mathbf{T S}_{\mathbf{1}}$ & $\mathbf{T S}_{\mathbf{4}}$ \\
\hline Moisture & 10 & 12 & 14 \\
\hline Ash & 1.0 & 1.7 & 2.6 \\
\hline Acid insoluble ash & 0.1 & 0.13 & 0.2 \\
\hline Protein & 14 & 15 & 17 \\
\hline Fat & 6.0 & 6.1 & 6.5 \\
\hline Carbohydrates & 69 & 65.2 & 60 \\
\hline Fiber & 2.30 & 3.8 & 6.86 \\
\hline Iron & 8.0 & 8.06 & 8.2 \\
\hline Vit-A (及-carotene) $\mathbf{m g}$ & - & 30 & 54 \\
\hline Energy (kcal) & 297 & 303 & 316 \\
\hline
\end{tabular}

Note: $\mathrm{TS}_{1}-35 \%$ Mango pulp and 5\% Milk powder; $\mathrm{TS}_{4}-50 \%$ Mango pulp and $10 \%$ Milk powder

Fig.1

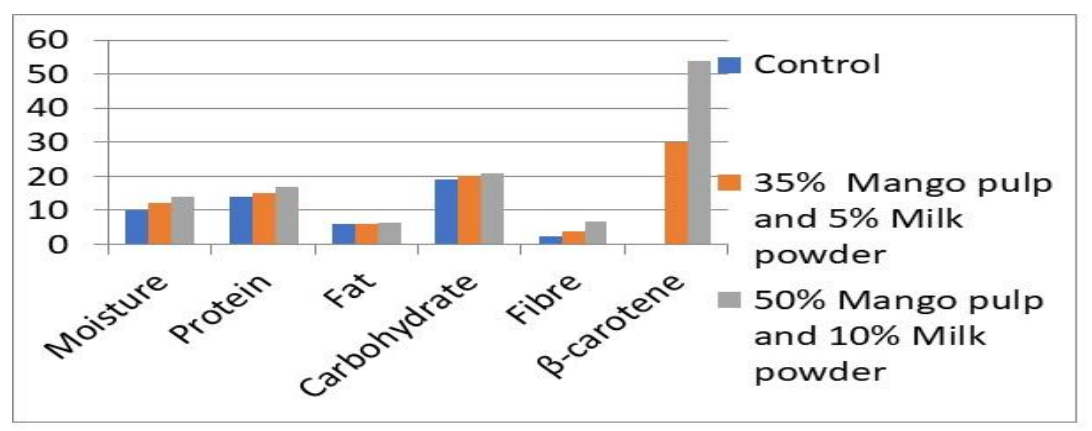

\section{Carbohydrates content}

The SamplesTS 1 and $\mathrm{TS}_{4}$ are low in carbohydrates content compare to the control. The level of mango pulp increases in cake decreases the carbohydrate content in cake. Because the mango fruit and milk powder contain low carbohydrates compare to wheat flour.
Vit-A ( $\beta$-carotene) content

Milk powder is very good source of Vitamin $A$ and this is evident from the chemical analysis as well. The Vitamin A content of the milk powder is $380 \mathrm{mg} / 100 \mathrm{~g}$.

In conclusion, bakery products such as biscuit, bread, cake and cookies are gaining 
popularity as processed food because of their availability as ready to eat, convenience and better shelf life. Mango provides vitamin A, a nutrient that's essential for proper functioning of the immune system. It can serve as a potential source of dietary fiber and minerals. The present study was carried out with the aim to develop cakes rich in Protein by incorporating milk powder at various levels and study the acceptability of the same. Cake was prepared from different levels of mango pulp and milk powder. The samples of control (Wheat flour $100 \%), \mathrm{TS}_{1}(35 \%$ mango pulp and $5 \%$ milk powder), $\mathrm{TS}_{2}(35 \%$ mango pulp and $10 \%$ milk powder), $\mathrm{TS}_{3}(50 \%$ mango pulp and $5 \%$ milk powder) and $\mathrm{TS}_{4}(50 \%$ mango pulp and $10 \%$ milk powder) and analyzed for organoleptic evaluation and chemical evaluation. The sample $\mathrm{TS}_{4}(50 \%$ mango pulp and $10 \%$ milk powder) was acceptable and 35\% mango pulp and 10\% milk powder incorporated cake was better in taste than control and $\mathrm{TS}_{3}$. Lower quantity of mango pulp tastes better but it affects the texture and colour. 50\% mango pulp and 10\% milk powder $\left(\mathrm{TS}_{4}\right)$ incorporated cake was more acceptable. The addition of mango pulp and milk powder at $50 \%$ and $10 \%$ to partially replacing wheat flour in cake formulation resulted in increment of protein, fat, ash, $\beta$ carotene and fibre content, as compared to control cake.

In summary the addition of mango pulp and milk powder resulted in an increase in the nutritional composition and sensory attributes, so that cake incorporated with $50 \%$ mango pulp and $10 \%$ milk powder are acceptable to consumers.

\section{References}

A.A.C.C., 2000. Approved Methods of AACC, American Association of Cereal Chemists, St. Paul, Minnesota.

Ajayi, C.M. Leelavathi, K. Prasad Rao, U.J.S.
(2005) Improvement of dietary fibre content and antioxidant properties in soft dough biscuits with the incorporation of mango peel powder. Journal of cereal science. 48 (2): 319326.

AOAC, Association of Official Analytical Chemist International (2010) Official methods of analysis of AOAC International.

Kamaljit, K., S. Baljeet and K. Amarjeet (2010). Preparation of bakery products by incorporating pea flour as a functional ingredient. American Journal of Food Technology, 5:130-135.

Kawai, K., K. Hando, R. Thuwapanichayanan, and Y. Hagura. 2016. Effect of stepwise baking on the structure, browning, texture, and in vitro starch digestibility of cookie. LWTFood Science and Technology 66:38489.

Kiran, V. R., Ramkumar, C., Ashwini, A., Ramya, H. N. (2018). Development of Biscuit Incorporated with Amla Pomace Powder and Soya Flour, Int. J. Advanced and innovative research.vol $7 / 5$.

Lee-Hoon Ho, Nurul ZaizulianaRois Anwar, MazaitulAkmaSuhaimi, Muhammad Amirul Shah Rosli and John Yew Huat Tang.(2017) Nutritional, Physical and Sensory Quality Evaluation of Sponge Cake Prepared by Substitution of Wheat Flour by Sweet Potato (Ipomoea spp.) Flours. World Applied Sciences Journal 35 (8): 1348-1360

Pandya (2009). Rheological study of layer cake batters made with milk protein and different starch sources. Journal of food engineering. 102(3): 272-277.

Rajeev Bhat, Lee Min, W. and Azaiah, A.A. (2011). Nutritional and sensory quality evaluation of sponge cake prepared by incorporation of high dietary fibre containing mango peel flour. 
International journal of food science and nutrition. 62(6): 559-567.

Richa Singh (2016). Development of fiber enriched bakery products by incorporating fruit pulp waste powder and their acceptability evaluation. Int. J. Adv. Res. Biol. Sci. 3(6): 222-226

Ugwuona, F.U, Ogara, J.L and Awogbenja, M.D (2012): Chemical and sensory quality of cakes formulated with wheat, soybeans and cassava flours, Indian Journal.L. Sci. 1 (2): 1-6.

Walstra, M. Hoda, H.M. Bekhit, M.A. Amr, E. Mohamad, Y.S. (1999). Effect of substitution of milk protein on aroma volatiles, chemical composition and sensory quality of wheat cookies. International journal of Food Science and Technology. 44(9): 1705-1712.

\section{How to cite this article:}

Ramya, H.N. and Anitha, S. 2020. Nutritional and Sensory Evaluation of Mango Pulp and Milk Powder Incorporated Sponge Cake. Int.J.Curr.Microbiol.App.Sci. 9(07): 71-79. doi: https://doi.org/10.20546/ijcmas.2020.907.008 